\title{
Effects of feeding hay and calf starter as a mixture or as separate components to Holstein calves on intake, growth, and blood metabolite and hormone concentrations
}

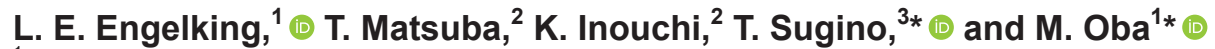 \\ ${ }^{1}$ Department of Agricultural, Food and Nutritional Science, University of Alberta, Edmonton, Alberta, Canada T6G 2P5 \\ ${ }^{2}$ Dairy Technology Research Institute, Feed-Livestock and Guidance Department, The National Federation of Dairy Co-operative Associations \\ (ZEN-RAKU-REN), Nishi-shirakawa, Fukushima, Japan 969-0223 \\ ${ }^{3}$ The Research Center for Animal Science, Graduate School of Integrated Sciences for Life, Hiroshima University, Higashi-Hiroshima, \\ Japan 739-8528
}

\begin{abstract}
This study investigated how providing hay mixed with calf starter to dairy calves affected their solid feed intake, feed sorting, growth, and plasma metabolite and hormone concentrations. Forty Holstein heifer calves were fed a texturized calf starter $(23.4 \%$ crude protein, $32.3 \%$ starch on a dry matter basis) and chopped Klein grass hay as separate components (CONT) or the same starter and hay mixed at a 90:10 ratio on an as-fed basis (MIX) ad libitum from the date transported to the research farm (4-7 d of life) to $90 \mathrm{~d}$ of life. Calves were provided milk replacer $(28 \%$ crude protein, $15 \%$ fat) at up to $557 \mathrm{~g} / \mathrm{d}$ before the study, $737 \mathrm{~g} / \mathrm{d}$ from d 14 to $20,1,105 \mathrm{~g} / \mathrm{d}$ from d 21 to $41,737 \mathrm{~g} / \mathrm{d}$ from d 42 to 48 , and $557 \mathrm{~g} / \mathrm{d}$ from d 49 to 55 on a dry matter basis. calves were fully weaned on d 56 . Feed sorting for the MIX calves was evaluated using the Penn State Particle Separator; the sorting index was calculated as the actual intake as a percentage of predicted intake, with values $>100 \%$ indicating sorting for and values $<100 \%$ indicating sorting against. Treatment did not affect solid feed intake, growth performance, or plasma metabolite or hormone concentration during the preweaning or weaning periods. However, calves in the MIX treatment had less neutral detergent fiber intake as a percentage of solid feed intake than CONT calves in the preweaning (23.3 vs. $37.0 \%)$ and weaning (23.5 vs. $25.8 \%$ ) periods, although MIX calves sorted $(107.2 \%)$ for long particles, which were primarily hay, during weaning. During the postweaning period, MIX calves had greater neutral detergent fiber intake as a percentage of solid feed intake compared with CONT

Received September 29, 2019.

Accepted December 24, 2019.

*Corresponding authors: sugino@hiroshima-u.ac.jp and moba@ ualberta.ca
\end{abstract}

calves (23.4 vs. $22.7 \%$ ), although they sorted against long particles $(84.4 \%)$, and decreased solid feed dry matter intake compared with CONT calves $(3,292$ vs. $3,536 \mathrm{~g} / \mathrm{d})$ and average daily gain (1.20 vs. 1.31 $\mathrm{kg} / \mathrm{d}$ ). Weaned calves in the MIX treatment also had lower plasma concentration of glucagon-like peptide 2 compared with CONT (0.46 vs. $0.77 \mathrm{ng} / \mathrm{mg}$ ) but had higher plasma concentrations of ghrelin (0.05 vs. 0.03 $\mathrm{ng} / \mathrm{mg})$. These results suggest that feeding a mixture of texturized calf starter and chopped hay at the 90:10 ratio to postweaned calves may decrease solid feed intake and growth.

Key words: dairy calf, hay, hay presentation, glucagonlike peptide 2 , ghrelin

\section{INTRODUCTION}

Providing hay to calves before weaning has been debated for many years, and the National Research Council currently does not have a recommendation (NRC, 2001) on how it should be provided. Hay inclusion in the preweaned diet has been controversial because it could decrease calf starter intake (Hill et al., 2008), which is the primary contributor to rumen papillae growth (Kertz et al., 1979). Adequate papillae growth is important because calves are born with undeveloped rumens and postnatal development is necessary for calves to be able to handle solid feed later in life (Khan et al., 2011a). However, some studies have reported that hay provision does not appear to hinder calf starter intake; in fact, hay intake may benefit calves through increased starter intake (Castells et al., 2012; Beiranvand et al., 2014b) as well as increased feed efficiency (Coverdale et al., 2004), rumen pH (Suárez et al., 2007; Khan et al., 2011b; Laarman and Oba, 2011), ADG (Imani et al., 2017), and rumen development (Castells et al., 2012).

While some previous studies have demonstrated benefits when hay is fed in addition to calf starter, the optimum way to present hay to calves early in life has 
not been evaluated. Hay is typically provided to calves separately from calf starter, which allows them to easily choose which type of feed to consume. Chopped hay and starter can also be combined and provided as a mixture to promote more consistent hay intake. If mixing hay and calf starter increases solid feed intake, it also has the potential to influence the growth and development of the calf (Beiranvand et al., 2014a). However, no recommendation exists for how hay should be provided to young calves for optimal growth and development. In addition, little information is available about the effects of solid feed intake on gut peptides regulating feed intake and gut development such as ghrelin and glucagon-like peptide (GLP) 2. We hypothesized that providing hay mixed with calf starter would promote more consistent hay intake and increase ADG. The objectives of this study were to evaluate the effects of mixing hay with calf starter on solid feed intake, ADG and plasma concentrations of peptide hormones of dairy calves during the first 3 mo in life.

\section{MATERIALS AND METHODS}

This study was conducted November 18 to February 26, 2018, at the Dairy Technology Research Institute of the National Federation of Dairy Co-operative Associations (Nishi-shirakawa, Fukushima, Japan). All procedures were approved by the Animal Care and Use Committee of Hiroshima University.

\section{Animals and Housing}

Forty Holstein female calves $(4-7 \mathrm{~d}$ of age, BW = $40.7 \pm 2.72 \mathrm{~kg}$; mean $\pm \mathrm{SD}$ ) were transported from commercial dairies in neighboring prefectures, Japan, to the Dairy Technology Research Institute (Yabuki, Fukushima, Japan). Calves were born between November 4 and November 27, 2017. Calves were blocked by birthdate, BW, and farm origin, and randomly assigned to 1 of 2 treatments differing in hay feeding approach $(\mathrm{n}=20$ for each treatment). Calves were raised outdoor in individual fiber-reinforced plastic hutches $(115 \times 230$ $\times 120 \mathrm{~cm}$ ) with sand flooring and sawdust for bedding. Hutches were cleaned twice daily at 0700 and $1400 \mathrm{~h}$, and bedding was added daily after the $1400 \mathrm{~h}$ cleaning. When calves arrived at the research farm, they received $5 \mathrm{~mL}$ of Terramycin LA (Zoetis Japan, Tokyo, Japan) and $0.5 \mathrm{~mL}$ of Duphafral Forte (Zoetis Japan) via subcutaneous injection and $5 \mathrm{~mL}$ of Ivermec PO (Fujita Pharm, Tokyo, Japan) via percutaneous absorption. In addition, all calves received $5 \mathrm{~mL}$ of Ektecin Liquid (Meiji Seika Pharma, Tokyo, Japan) daily for 3 consecutive days after arrival and $15 \mathrm{~mL}$ of Baycox Bovis
(Bayer Yakuhin, Osaka, Japan) on d 21 of life via oral administration.

\section{Feeding}

All calves were fed a milk replacer (MR; $28 \% \mathrm{CP}$ and $15 \%$ fat; $166.7 \mathrm{~g} / \mathrm{L})$ using a bucket with a soft rubber nipple twice daily at 0615 and $1615 \mathrm{~h}$. Each liter of MR contained $200 \mathrm{~g}$ of MR powder. Before the study, MR was offered at up to $557 \mathrm{~g} / \mathrm{d}$. When the study began, $737 \mathrm{~g} / \mathrm{d}$ of MR was provided from d 14 to $20,1,105 \mathrm{~g} / \mathrm{d}$ from d 21 to $41,737 \mathrm{~g} / \mathrm{d}$ from d 42 to 48 , and $557 \mathrm{~g} / \mathrm{d}$ from d 49 to 55 on a DM basis. Calves were fully weaned on d 56. All calves had free access to fresh water supplied by bucket. Calves were fed a texturized calf starter $(23.4 \%$ CP, $32.3 \%$ starch, $20.8 \%$ NDF on a DM basis; Tables 1 and 2) and chopped Klein grass hay $(10.0 \% \mathrm{CP}, 68.6 \% \mathrm{NDF}$ on DM basis) separately (CONT) or the same starter and hay mixed at a 90:10 ratio on an as-fed basis (MIX). Klein grass hay was chopped to a theoretical length of $19 \mathrm{~mm}$ by a cutting machine (CX-201; Yamamoto Co., Ltd., Tendo, Yamagata, Japan). The MIX ration was prepared by mixing the calf starter and chopped hay for 2 min using a ribbon mixer (RM-500, Fuji Electric Industry Co., Ltd., Kyoto, Japan). Particle distribution of the MIX ration was $1.2,14.2,82.3$, and $2.3 \%$ on the upper sieve, second sieve, third sieve, and bottom pan of Penn State Particle Separator, respectively. Calf starter and chopped hay for the CONT treatment and the mixed ration for the MIX treatment were offered ad libitum from 8-L buckets from d 14. Feeding time of solid feed was $1000 \mathrm{~h}$ initially, but when calves consumed more than $700 \mathrm{~g} / \mathrm{d}$ (as fed) of starter or mixed ration, respectively, they were fed twice daily (equal amounts at 1000 and $1500 \mathrm{~h}$ ). Refused calf starter, hay, and mixed ration were collected daily at $1000 \mathrm{~h}$, and each calf's intake was recorded.

\section{Data and Sample Collection}

Feed intake for individual calves was recorded daily, and BW was recorded weekly. Body weight, withers height, hip height, horizontal body length, hip width, and heart girth were measured at $0930 \mathrm{~h}$ at the start of the trial (d 14) and weekly thereafter until the end of the trial (d 91).

Blood was collected weekly at $0930 \mathrm{~h}$ starting at d 14 using Vacutainers for plasma collection (Venoject II VP-H100K with heparin sodium, Terumo Corp., Tokyo, Japan). Aprotinin (500 kallikrein inhibitor units/mL of blood; Sigma-Aldrich Inc., Tokyo, Japan) was added to blood samples immediately after collection for plasma 
Table 1. Dry matter ratio of ingredients in calf starter formulation

\begin{tabular}{lc}
\hline Item & Composition \\
\hline Ingredient, \% of DM & \\
Steam-flaked barley grain & 20.2 \\
Steam-flaked corn grain & 9.9 \\
Beet pulp pellet & 4.1 \\
Alfalfa dehydrated pellet & 3.7 \\
Molasses cane & 0.4 \\
Pellet & 61.7 \\
Pellet, \% of DM & \\
Soybean meal & 17.3 \\
Dry ground corn & 14.9 \\
Wheat bran & 9.0 \\
Heated soybean & \\
Corn gluten meal & 7.07 \\
Soybean flour & 2.31 \\
Wheat feed flour & 2.20 \\
Rapeseed meal & 1.59 \\
Cane molasses & 1.26 \\
Calcium carbonate & 3.35 \\
Salt & 1.16 \\
Calcium phosphate & 0.71 \\
Premix of trace minerals and vitamins & \\
\hline
\end{tabular}

${ }^{1}$ Heated soybean (SoyPlus, West Central Cooperative, Ralston, IA).

${ }^{2}$ Contained 2,905 $\mathrm{kIU} / \mathrm{kg}$ vitamin $\mathrm{A}, 600 \mathrm{kIU} / \mathrm{kg}$ vitamin $\mathrm{D}, 29,800$ $\mathrm{mg} / \mathrm{kg}$ vitamin E, 1,200 $\mathrm{mg} / \mathrm{kg}$ thiamin, $1,200 \mathrm{mg} / \mathrm{kg}$ riboflavin, 2,400 $\mathrm{mg} / \mathrm{kg}$ pantothenic acid, $4,780 \mathrm{mg} / \mathrm{kg}$ niacin, $720 \mathrm{mg} / \mathrm{kg}$ pyridoxin, $24 \mathrm{mg} / \mathrm{kg}$ biotin, $50 \mathrm{mg} / \mathrm{kg}$ folate, $35,720 \mathrm{mg} / \mathrm{kg}$ choline, and $5 \mathrm{mg} /$ $\mathrm{kg}$ vitamin $\mathrm{B}_{12}$.

preparation. Blood samples were then centrifuged at $1,800 \times g$ at $4^{\circ} \mathrm{C}$ for 20 min and plasma was collected. Plasma samples were stored at $-80^{\circ} \mathrm{C}$ until analysis.

\section{Sample Analyses}

Calf starter, hay, and MIX were sampled weekly, composited monthly, and stored at room temperature. Feed refusals were sampled daily, composited weekly, air-dried at $60^{\circ} \mathrm{C}$ for $48 \mathrm{~h}$, and stored at room temperature. Particle distribution of MIX and feed refusals for calves fed MIX were analyzed using a 3-screen (19, 8, and $1.18 \mathrm{~mm}$ ) Penn State Particle Separator according to Kononoff et al. (2003). Particles were separated by size into 4 fractions; long $(>19 \mathrm{~mm})$, medium $(<19$ to $>8 \mathrm{~mm})$, short $(<8$ to $>1.18 \mathrm{~mm})$, and fine $(<1.18 \mathrm{~mm})$ particles. A sorting index above 100 indicated sorting for particles, and a sorting index below 100 indicated sorting against particles (Leonardi and Armentano, 2003).

The samples were ground using a hammer mill (SM1, Retsch GmbH, Haan, Germany) with a 1-mm screen and analyzed by Zen-Raku-Ren Analysis Center (Kamisu, Ibaraki, Japan) for concentrations of DM, ash, CP, ether extract, and starch according to AOAC (1990) and for NDF according to AOAC International (2002).

Plasma samples were analyzed for IGF-1, GLP-2, ghrelin, free fatty acids, glucose, and BHB concentrations. Plasma concentrations of IGF-1, GLP-2, and ghrelin were measured by the competitive time-resolved fluoroimmunoassay technique using a 2030 Multilabel Reader ARVO X4 (PerkinElmer Inc., Waltham, MA). Ghrelin and IGF-1 were extracted before analysis by using acetone and then evaporated and resuspended in a Tris buffer containing $10 \mathrm{U} / \mathrm{mL}$ of aprotinin as described in Sugino et al. (2002). The plasma IGF-1 concentration was measured using Eu-labeled human IGF-1 and polystyrene microtiter strips (Nalgene Nunc Int., Tokyo, Japan) coated with anti-rabbit $\gamma$-globulin (Laarman et al., 2012a).

Plasma GLP-2 concentrations were measured with Eu-labeled human GLP-2 (Peptide Institute Inc., Osaka, Japan), Eu-labeled human GLP-2 (Yanaihara Institute Inc., Shizuoka, Japan), and polystyrene microtiter strips coated with goat-anti-rabbit $\gamma$-globulin (Elsabagh et al., 2017). Plasma ghrelin concentrations were measured using Eu-labeled synthetic bovine ghrelin, polyclonal anti-rat ghrelin, and polystyrene microtiter strips (Nalge Nunc Int., Tokyo, Japan) coated with anti-rabbit $\gamma$-globulin (Fukumori et al., 2012). The plasma concentration of metabolites were enzymatically assayed on a Beckman Coulter chemistry analyzer (AU480; Beckman Coulter Inc., Brea, CA)

\section{Statistical Analysis}

All data were analyzed separately for 3 periods differing in primary nutrient sources: preweaning (d 14-41),

Table 2. Nutrient composition of calf starter, Klein grass hay, and MIX ration; mean \pm SD

\begin{tabular}{lrrr}
\hline Composition & Calf starter & Klein grass hay & MIX $^{1}$ \\
\hline DM, \% & $87.5 \pm 0.17$ & $92.5 \pm 0.21$ & $88.5 \pm 0.12$ \\
Nutrient component, \% of DM & $23.4 \pm 0.20$ & $10.0 \pm 0.98$ & $20.9 \pm 0.61$ \\
CP & $3.9 \pm 0.12$ & $1.6 \pm 0.15$ & $3.7 \pm 0.40$ \\
Ether extract & $6.8 \pm 0.15$ & $8.5 \pm 0.35$ & $6.8 \pm 0.45$ \\
Ash & $20.9 \pm 3.69$ & $68.6 \pm 1.61$ & $23.9 \pm 0.40$ \\
NDF & $32.2 \pm 3.00$ & $0.7 \pm 0.40$ & $29.1 \pm 2.27$ \\
Starch & & \\
\hline
\end{tabular}

${ }^{1} \mathrm{MIX}=$ calf starter and chopped Klein grass hay were mixed at a 90:10 ratio on an as-fed basis. 
during weaning (d 42-55), and postweaning (d 56-90). Data were analyzed using JMP Pro 14.2 (SAS Institute Inc., Cary, NC) according to the following model using compound symmetry as a covariance structure:

$$
\mathrm{Y}_{\mathrm{ijk}}=\mu+\mathrm{T}_{\mathrm{i}}+\mathrm{W}_{\mathrm{j}}+\mathrm{TW}_{\mathrm{ij}}+\mathrm{C}_{\mathrm{k}}+\mathrm{e}_{\mathrm{ijk}},
$$

where $Y_{\mathrm{ijk}}$ is the dependent variable, $\mu$ is overall mean, $T_{i}$ is fixed effect of treatment, $W_{j}$ is the fixed effect of week used as a repeated measure, $\mathrm{TW}_{\mathrm{ij}}$ is the effect of treatment by week interaction, $\mathrm{C}_{\mathrm{k}}$ is the random effect of calf, and $\mathrm{e}_{\mathrm{ijk}}$ is the residual. For analysis of intake and growth data, initial BW on d 7 was used as a covariate. Sorting index for MIX calves was tested for a difference from $100 \%$ by using the TTEST procedure. Treatment effects were declared significant at $P<0.05$, and tendencies were declared at $0.05 \leq P<0.10$.

\section{RESULTS}

\section{Intake}

No differences in MR $(P=0.55)$ or solid feed intake were found between treatments in the preweaning period (Table 3). Starch and NDF intake (Figure 1A) also did not differ between treatments in the preweaning period. During weaning, no differences were observed

Table 3. Effects of feeding hay and calf starter as a mixture or as separate components on DMI and nutrient intake $(\mathrm{g} / \mathrm{d})$ preweaning $(\mathrm{d}$ 7-41), weaning (d 42-55), and postweaning (d 56-90); LSM \pm SEM

\begin{tabular}{|c|c|c|c|c|}
\hline \multirow[b]{2}{*}{ Item } & \multicolumn{2}{|c|}{ Treatment $^{1}$} & \multirow[b]{2}{*}{$\mathrm{SE}$} & \multirow[b]{2}{*}{$P$-value } \\
\hline & $\begin{array}{c}\text { CONT } \\
(\mathrm{n}=20)\end{array}$ & $\begin{array}{c}\text { MIX } \\
(\mathrm{n}=20)\end{array}$ & & \\
\hline \multicolumn{5}{|c|}{ Preweaning (d 14-41) } \\
\hline Total DMI ${ }^{2}$ & 1,167 & 1,192 & 71 & 0.54 \\
\hline Solid feed DMI ${ }^{3}$ & 163 & 195 & 71 & 0.41 \\
\hline Starch intake & 46 & 56.1 & 22 & 0.41 \\
\hline NDF intake & 51 & 52 & 15 & 0.91 \\
\hline \multicolumn{5}{|l|}{ Weaning (d 42-55) } \\
\hline Total DMI ${ }^{2}$ & 1,885 & 1,801 & 87 & 0.45 \\
\hline Solid feed DMI & 1,240 & 1,155 & 87 & 0.45 \\
\hline Starch intake & 370 & 336 & 27 & 0.35 \\
\hline NDF intake & 308 & 278 & 19 & 0.22 \\
\hline \multicolumn{5}{|c|}{ Postweaning (d 56-90) } \\
\hline Solid feed DMI & 3,536 & 3,292 & 67 & $<0.05$ \\
\hline Starch intake & 1,098 & 966 & 21 & $<0.01$ \\
\hline NDF intake & 800.3 & 772 & 14 & 0.43 \\
\hline
\end{tabular}

${ }^{1}$ CONT was fed the calf starter and hay separately. MIX was fed calf starter mixed with chopped Klein grass hay at 90:10 ratio on an asfed basis.

${ }^{2}$ Total DMI was the sum of milk replacer, calf starter and hay.

${ }^{3}$ Solid feed intake was the sum of calf starter and hay. The CONT calves consumed calf starter and hay at $73 \pm 5: 27 \pm 5,84 \pm 4: 17 \pm$ 4, and $96 \pm 0.4: 4 \pm 0.4$ ratios on an as-fed basis preweaning, weaning, and postweaning, respectively. in total DMI, solid feed intake, starch, or NDF intake. In the postweaning period, calves in the MIX treatment had a lower DMI compared with CONT calves $(3,292$ vs. $3,536 \mathrm{~g} / \mathrm{d})$. Calves in the MIX treatment had lower starch intake compared with CONT calves (966 vs. $1,098 \mathrm{~g} / \mathrm{d}$ ), but NDF intake did not differ.

In the weaning period, MIX calves sorted for long (Table 4) and short particles (104.5\%) and sorted against medium (79.3\%) and fine particles (63.4\%).
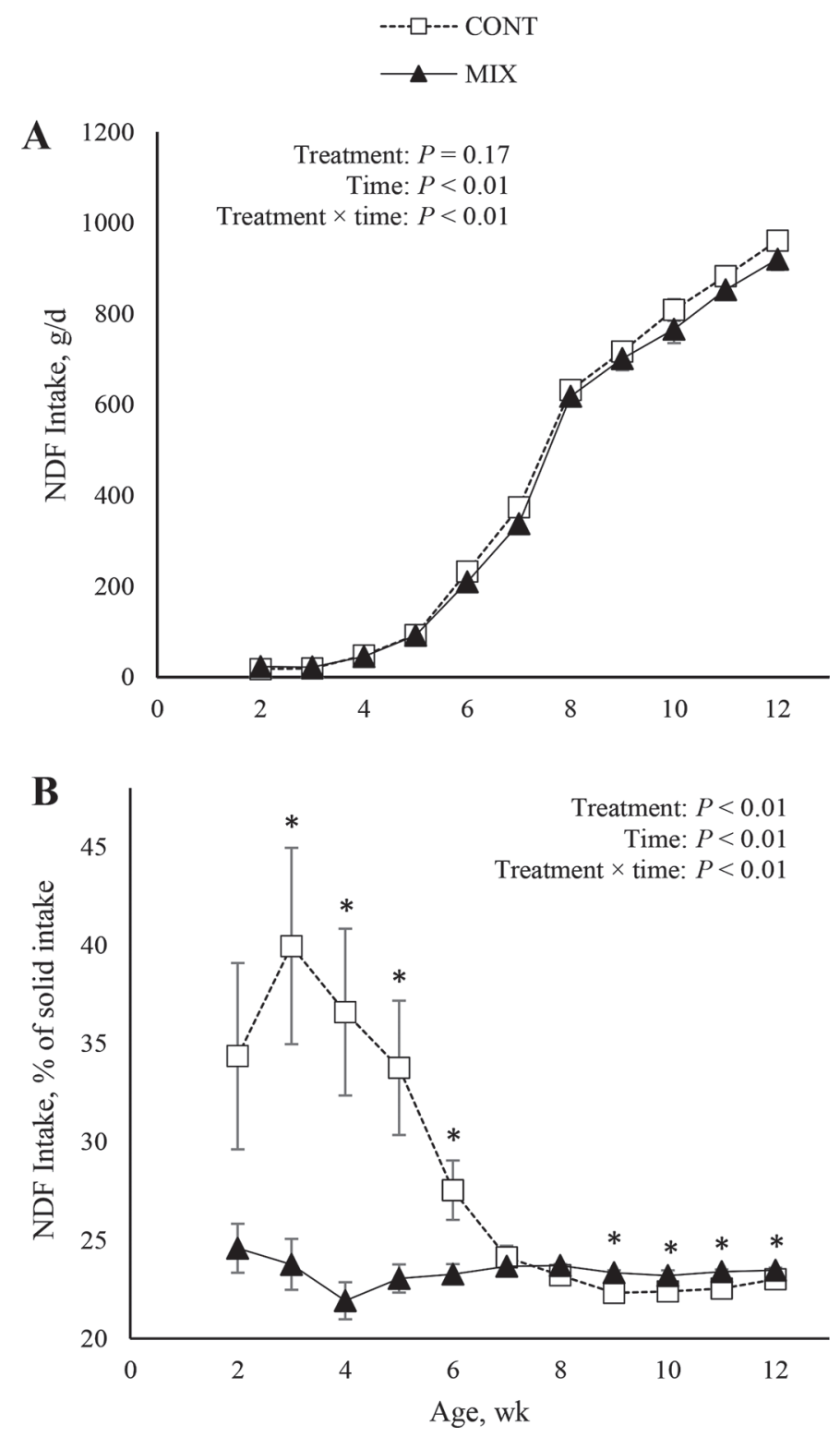

Figure 1. (A) Intake of NDF (g/d) and (B) intake of NDF as a percentage of solid feed DMI as a proportion of solid feed intake (\%) of calves fed hay and calf starter as separate components (COMT) or as a mixture (MIX). Results are expressed as LSM \pm SEM. *Differences between treatments at each time point are significant $(P<0.05)$. 
Postweaned calves in the MIX treatment sorted for short particles (102\%) and sorted against long (84\%), medium particles (91\%), and fine particles (80\%).

During the preweaning period, MIX calves had less NDF intake, as a percentage of solid feed DMI (NDFIP), compared with CONT (23.3 vs. 37.0\%; Table 5 and Figure 1B) and more starch, as a percentage of solid feed DMI, compared with CONT calves (28.9 vs. $21.6 \%)$. In the weaning period, MIX calves had less NDFIP (23.5 vs. 25.8\%) than CONT calves. Postweaned MIX calves had more NDFIP (23.4 vs. $22.7 \%$ ), but less starch, as a percentage of solid feed DMI than CONT calves (29.4 vs. $31.0 \%$ ).

\section{Growth}

Preweaning ADG and feed efficiency were not affected by treatment (Table 6). During weaning, no difference was found in ADG, but feed efficiency was lower for MIX than CONT calves (0.50 vs. $0.53 \mathrm{~kg} / \mathrm{kg}$ $\mathrm{DM})$. For the postweaning period, calves in the MIX treatment had lower ADG than CONT (1.20 vs. 1.31 $\mathrm{kg} / \mathrm{d}$ ), but feed efficiency did not differ.

\section{Plasma Metabolites and Hormones}

In the preweaning period, no differences were observed between treatments for plasma concentrations of ghrelin (Table 7 and Figure 2A), GLP-2 (Figure 2B), IGF-1 (Figure 2C), free fatty acids (Figure 2D), glucose (Figure 2E), or BHB (Figure 2F). During the weaning period, no differences were present in plasma concentrations of ghrelin, GLP-2, IGF-1, free fatty ac-

Table 4. Sorting index of calves fed hay and calf starter as a mixture during weaning (d 42-55) and postweaning periods (d 56-90); mean $\pm \mathrm{SEM}$

\begin{tabular}{lrrr}
\hline Item & $\begin{array}{c}\text { Sorting } \\
\text { index }^{1}\end{array}$ & SEM & $P$-value \\
\hline Weaning (d 42-55) & 107.2 & 1.48 & $<0.01$ \\
$\quad$ Long & 79.3 & 3.15 & $<0.01$ \\
Medium & 104.5 & 0.55 & $<0.01$ \\
Short & 63.4 & 1.72 & $<0.01$ \\
$\quad$ Fine & & & \\
Postweaning (d 56-90) & 84.4 & 2.05 & $<0.01$ \\
Long & 91.1 & 1.52 & $<0.01$ \\
Medium & 102.3 & 0.27 & $<0.01$ \\
Short & 80.1 & 1.44 & $<0.01$ \\
Fine & & & \\
\hline
\end{tabular}

${ }^{1}$ Sorting index was calculated as the ratio of actual intake to predicted intake for particle retained on each sieve of the Penn State Particle Separator (>19.0 mm, 8.0-19.0 mm, 1.18-8.0 mm, and <1.18 mm). A sorting index $>100$ indicates sorting for particles, and a sorting index $<100$ indicates sorting against particles (Leonardi and Armentano, 2003).
Table 5. Effects of feeding hay and calf starter as a mixture or as separate components on intake, as percentage of total solid DMI $(\%$ of solid feed intake ${ }^{1}$ ) preweaning (d 14-41), weaning (d 42-55), and postweaning (d 56-90); LSM \pm SEM $^{2}$

\begin{tabular}{lcccc}
\hline & \multicolumn{2}{c}{ Treatment $^{3}$} & & \\
\cline { 2 - 3 } & $\begin{array}{c}\text { CONT } \\
\text { Item }\end{array}$ & $\begin{array}{c}\text { MIX } \\
(\mathrm{n}=20)\end{array}$ & SE & P-value \\
\hline $\begin{array}{l}\text { Preweaning (d 14-41) } \\
\quad \text { Starch }\end{array}$ & 21.6 & 28.9 & 1.88 & $<0.05$ \\
$\quad 37.0$ & 23.3 & 2.83 & $<0.01$ \\
$\quad$ NDF & 28.9 & 29.1 & 0.49 & 0.76 \\
$\quad$ Starch & 25.8 & 23.5 & 0.75 & $<0.05$ \\
$\quad$ NDF & 31.0 & 29.4 & 0.12 & $<0.01$ \\
Postweaning (d 56-90) & 22.7 & 23.4 & 0.18 & $<0.01$ \\
$\quad$ Starch & &
\end{tabular}

${ }^{1}$ Solid feed intake was the sum of calf starter and hay.

${ }^{2}$ The CONT calves consumed calf starter and hay at $73 \pm 5: 27 \pm 5,84$ $\pm 4: 17 \pm 4$, and $96 \pm 0.4: 4 \pm 0.4$ ratios on an as-fed basis preweaning, weaning, and postweaning, respectively.

${ }^{3} \mathrm{CONT}$ was fed the calf starter and hay separately. MIX was fed calf starter mixed with chopped Klein grass hay at 90:10 ratio on an asfed basis.

ids, glucose, or BHB. In the postweaning period, no differences occurred in plasma concentration of IGF1 , free fatty acids, glucose, or BHB. However, in the postweaning period, calves in the MIX treatment had higher plasma concentrations of ghrelin in wk 8 and 10 and lower plasma concentrations of GLP-2 in wk 10 than CONT calves.

\section{DISCUSSION}

\section{Preweaning Period}

In the preweaning period, neither MR and solid feed intake nor plasma metabolite and hormone concentrations were affected by treatment, similar to previous research results (Miller-Cushon et al., 2013; EbnAli et al., 2016; Overvest et al., 2016). As calf intake was primarily $\mathrm{MR}$ in this period, solid feed intake might have been too low for a difference in blood metabolites or hormones or in intake to be detected (Overvest et al., 2016). Interestingly, while NDF intake (g/d) did not differ between treatments, MIX calves had a lower NDFIP compared with CONT calves. What CONT calves consumed may reflect calf preferences more closely than what MIX calves consumed. Because they were fed hay and calf starter at a fixed ratio, the MIX calves had greater difficulty selecting certain feed components. In contrast, CONT calves were able to select preferred feed. This suggests that calves may consume hay at more than $10 \%$ of solid feed intake before the weaning period when provided free choice hay. 
Table 6. Effects of feeding hay and calf starter as a mixture or as separate components on growth preweaning (d 14-41), weaning (d 42-55), and postweaning (d 56-90); LSM \pm SEM

\begin{tabular}{|c|c|c|c|c|}
\hline \multirow[b]{2}{*}{ Item } & \multicolumn{2}{|c|}{ Treatment $^{1}$} & \multirow[b]{2}{*}{ SE } & \multirow[b]{2}{*}{$P$-value } \\
\hline & $\begin{array}{c}\text { CONT } \\
(\mathrm{n}=20)\end{array}$ & $\begin{array}{c}\text { MIX } \\
(\mathrm{n}=20)\end{array}$ & & \\
\hline \multicolumn{5}{|l|}{ Preweaning (d 14-41) } \\
\hline $\mathrm{ADG}, \mathrm{kg} / \mathrm{d}$ & 0.92 & 0.93 & 0.027 & 0.71 \\
\hline Withers height gain, $\mathrm{cm} / \mathrm{d}$ & 0.25 & 0.24 & 0.010 & 0.62 \\
\hline Hip height gain, cm/d & 0.28 & 0.25 & 0.015 & 0.25 \\
\hline Heart girth gain, $\mathrm{cm} / \mathrm{d}$ & 0.45 & 0.49 & 0.016 & 0.10 \\
\hline Horizontal body length gain, $\mathrm{cm} / \mathrm{d}$ & 0.34 & 0.29 & 0.017 & 0.05 \\
\hline Hip width gain, $\mathrm{cm} / \mathrm{d}$ & 0.12 & 0.11 & 0.001 & 0.55 \\
\hline Feed efficiency, ${ }^{2} \mathrm{~kg} / \mathrm{kg}$ of DM & 0.81 & 0.80 & 0.016 & 0.55 \\
\hline \multicolumn{5}{|l|}{ Weaning (d 42-55) } \\
\hline $\mathrm{ADG}, \mathrm{kg} / \mathrm{d}$ & 0.99 & 0.90 & 0.045 & 0.17 \\
\hline Withers height gain, $\mathrm{cm} / \mathrm{d}$ & 0.29 & 0.31 & 0.020 & 0.47 \\
\hline Hip height gain, cm/d & 0.24 & 0.28 & 0.027 & 0.55 \\
\hline Heart girth gain, $\mathrm{cm} / \mathrm{d}$ & 0.42 & 0.41 & 0.035 & 0.94 \\
\hline Horizontal body length gain, $\mathrm{cm} / \mathrm{d}$ & 0.36 & 0.42 & 0.037 & 0.26 \\
\hline Hip width gain, $\mathrm{cm} / \mathrm{d}$ & 0.09 & 0.11 & 0.012 & 0.30 \\
\hline Feed efficiency, ${ }^{2} \mathrm{~kg} / \mathrm{kg}$ of DM & 0.53 & 0.50 & 0.012 & $<0.05$ \\
\hline \multicolumn{5}{|l|}{ Postweaning (d 56-90) } \\
\hline $\mathrm{ADG}, \mathrm{kg} / \mathrm{d}$ & 1.31 & 1.20 & 0.026 & $<0.01$ \\
\hline Withers height gain, $\mathrm{cm} / \mathrm{d}$ & 0.32 & 0.31 & 0.009 & 0.74 \\
\hline Hip height gain, $\mathrm{cm} / \mathrm{d}$ & 0.32 & 0.31 & 0.012 & 0.46 \\
\hline Heart girth gain, $\mathrm{cm} / \mathrm{d}$ & 0.44 & 0.39 & 0.013 & 0.02 \\
\hline Horizontal body length gain, $\mathrm{cm} / \mathrm{d}$ & 0.41 & 0.38 & 0.018 & 0.25 \\
\hline Hip width gain, $\mathrm{cm} / \mathrm{d}$ & 0.12 & 0.11 & 0.005 & 0.29 \\
\hline Feed efficiency, ${ }^{2} \mathrm{~kg} / \mathrm{kg}$ of DM & 0.38 & 0.38 & 0.008 & 0.45 \\
\hline
\end{tabular}

${ }^{1}$ CONT calves were fed the calf starter and hay separately. MIX calves were fed the mixed ration (mixing with calf starter and Klein grass hay at 90:10 ratio on an as-fed basis).

${ }^{2}$ Feed efficiency was calculated to as the ratio of ADG $(\mathrm{kg} / \mathrm{d}$ ) to total DMI (sum of milk replacer, calf starter, and hay; $\mathrm{kg} / \mathrm{d})$.

\section{Weaning Period}

During the weaning period, NDFIP continued to be lower for MIX calves compared with CONT, although MIX calves sorted for long particles, which was primarily hay. Feed sorting is commonly associated with TMR feeding in cattle, even from a young age (MillerCushon and DeVries, 2015, 2017). Young ruminants select feeds with nutrient contents that promote health and growth (Kyriazakis and Oldham, 1993; Bach et al., 2012; Miller-Cushon and DeVries, 2015). Miller-Cushon et al. (2013) reported that preweaned calves sorted for hay and against nonfiber carbohydrates, which perhaps limits the negative effects associated with lowered rumen pH (Costa et al., 2016). Sorting by calves may also depend on the other types of feed available to them (Miller-Cushon et al., 2013). In the present study, the sorting demonstrated by MIX calves may have been due to sufficient energy intake from MR to meet requirement. These calves may not have relied on energy intake from calf starter as much as MR (Miller-Cushon and DeVries, 2015); instead, they opted for hay, perhaps to prevent health implications associated with a low rumen pH (Keunen et al., 2002; Costa et al., 2016).
Calves in the CONT treatment had free access to hay, which led to greater NDFIP. The sorting behavior of MIX calves during the weaning period may indicate that, as in the preweaning period, MIX calves preferred more than the $10 \%$ hay provided in the mixture. However, NDFIP of CONT calves during the weaning period decreased compared with the preweaning period ( 25.8 vs. $37.0 \%$ ), which suggests that calf preference for hay may decrease with declining milk allowance.

During the weaning period, no differences in growth, intake, or blood metabolites and hormones were observed, but feed efficiency was lower for MIX calves. This outcome may be due to the lower NDFIP of MIX calves, similar to results from Montoro et al. (2013), who reported that hay intake increased feed efficiency. This increase is possibly attributable to rumination induced by NDF in hay, stimulating salivary buffer secretion and raising rumen $\mathrm{pH}$ (Allen, 1997; Laarman et al., 2012b; Pazoki et al., 2017). This buffer is necessary to counteract $\mathrm{pH}$ reductions from starch fermentation (Forbes and Provenza, 2000; Khan et al., 2008). Starch intake during weaning did not differ, but because MIX calves had lower NDFIP, they may have had a lower rumen $\mathrm{pH}$ than CONT calves. Low rumen $\mathrm{pH}$ is associated 
Table 7. Effects of feeding hay and calf starter as a mixture or as separate components on plasma hormones and metabolites preweaning (d 14-41), weaning (d 42-55), and postweaning (d 56-90); mean \pm SEM

\begin{tabular}{|c|c|c|c|c|}
\hline \multirow[b]{2}{*}{ Item } & \multicolumn{2}{|c|}{ Treatment $^{1}$} & \multirow[b]{2}{*}{$\mathrm{SE}$} & \multirow[b]{2}{*}{$P$-value } \\
\hline & $\begin{array}{c}\text { CONT } \\
(\mathrm{n}=20)\end{array}$ & $\begin{array}{c}\text { MIX } \\
(\mathrm{n}=20)\end{array}$ & & \\
\hline \multicolumn{5}{|l|}{ Preweaning (d 14-41) } \\
\hline $\mathrm{IGF}-1, \mathrm{ng} / \mathrm{mg}$ & 57.8 & 59.6 & 3.78 & 0.74 \\
\hline GLP- $2,{ }^{2} \mathrm{ng} / \mathrm{mg}$ & 0.67 & 0.69 & 0.09 & 0.90 \\
\hline Ghrelin, ng/mg & 0.06 & 0.07 & 0.01 & 0.68 \\
\hline Free fatty acids, $\mu \mathrm{Eq} / \mathrm{L}$ & 73.6 & 84.0 & 5.75 & 0.21 \\
\hline Glucose, $\mathrm{mg} / \mathrm{dL}$ & 121 & 119 & 3.27 & 0.60 \\
\hline $\mathrm{BHB}, \mu \mathrm{mol} / \mathrm{L}$ & 66.9 & 71.0 & 3.84 & 0.45 \\
\hline \multicolumn{5}{|l|}{ Weaning (d 42-55) } \\
\hline IGF-1, ng/mg & 100 & 114 & 9.62 & 0.32 \\
\hline GLP-2, ng/mg & 0.65 & 0.58 & 0.07 & 0.49 \\
\hline Ghrelin, ng/mg & 0.07 & 0.06 & 0.01 & 0.45 \\
\hline Free fatty acids, $\mu \mathrm{Eq} / \mathrm{L}$ & 91.2 & 93.2 & 7.36 & 0.85 \\
\hline Glucose, $\mathrm{mg} / \mathrm{dL}$ & 124 & 118 & 3.21 & 0.23 \\
\hline $\mathrm{BHB}, \mu \mathrm{mol} / \mathrm{L}$ & 106 & 114 & 9.26 & 0.55 \\
\hline \multicolumn{5}{|l|}{ Postweaning (d 56-70) } \\
\hline IGF-1, ng/mg & 109 & 96.7 & 7.70 & 0.26 \\
\hline GLP-2, ng/mg & 0.77 & 0.46 & 0.08 & $<0.05$ \\
\hline Ghrelin, ng/mg & 0.03 & 0.05 & 0.01 & $<0.01$ \\
\hline Free fatty acids, $\mu \mathrm{Eq} / \mathrm{L}$ & 92.5 & 101 & 5.73 & 0.28 \\
\hline Glucose, $\mathrm{mg} / \mathrm{dL}$ & 113 & 110 & 1.59 & 0.19 \\
\hline $\mathrm{BHB}, \mu \mathrm{mol} / \mathrm{L}$ & 389 & 401 & 21.5 & 0.70 \\
\hline
\end{tabular}

${ }^{1}$ Treatment: CONT calves were fed the calf starter and hay separately, MIX calves were fed the mixed ration (mixing with calf starter and Klein grass hay at a 90:10 ratio on an as-fed basis).

${ }^{2} \mathrm{GLP}=$ glucagon-like peptide.

with release of LPS from gram-negative bacteria (Nocek, 1997), which is absorbed into the bloodstream and causes systemic inflammation (Horadagoda et al., 1999; Khafipour et al., 2009). If calves in the MIX treatment were experiencing inflammation, their immune system would require more energy to counteract the inflammation (Bertoni et al., 2008). This greater energy demand would thus reduce the amount of energy available for growth, decreasing feed efficiency (Trevisi et al., 2010).

\section{Postweaning Period}

Intake and Growth. A change occurred in NDFIP over time. Calves in the CONT treatment had a higher amount of NDFIP in the preweaning period, but NDFIP declined as weaning began and became lower than in MIX calves during the postweaning period. This finding may indicate that calves prefer less NDFIP in the postweaning period, compared with the preweaning and weaning periods, and that the optimum amount of hay included in the diet may change as a calf ages. In contrast to CONT calves, calves in the MIX treatment maintained a relatively constant NDFIP throughout the experiment, regardless of period. It appears MIX calves also attempted to decrease their postweaning NDFIP by sorting against long particles, which was primarily hay, similar to postweaned calves (Miller-Cushon and DeVries, 2011) and cattle (DeVries et al., 2007) in previous studies. However, despite sorting, MIX calves still had a higher NDFIP compared with CONT calves. This outcome is explained by CONT calves being easily able to reduce hay intake, whereas MIX calves received a fixed $10 \%$ of hay. Decreasing their NDFIP required sorting. It is likely that MIX calves consumed more hay because their ration was a mixture. As they attempted to consume starter, they consumed more hay than intended. Neutral detergent fiber is a primary contributor to rumen fill (Dado and Allen, 1995), and because MIX calves had a greater proportion of NDF in each bite, they likely experienced faster rumen fill than CONT calves, decreasing intake (Chilibroste et al., 1997; Gregorini et al., 2007). Although MIX calves had greater NDFIP, their NDF intake was similar to that of CONT calves, and they likely stopped eating upon reaching a certain intake of NDF. Because MIX calves reached their maximum NDF intake earlier due to greater NDFIP, their overall intake was lower, despite attempting to sort against long particles.

The reductions in NDFIP demonstrated by CONT calves over time may have been in response to the change in nutrient provision; calves in the preweaning period had access to high volumes of milk, which would meet the majority of their energy requirement (MillerCushon and DeVries, 2015) as previously described. Costa et al. (2016) provided young calves with free choice calf starter in addition to a TMR composed of starter, silage, and hay, and found that calves sorted for long particles in the TMR initially. However, when calf starter was removed and only the TMR was available, calves changed their sorting preference to fine particles, as they no longer had free choice starter as an energy source. In the present study, MIX calves sorted for long particles, which were primarily hay, when they were also provided MR, but when MR provision declined, the calves started to sort against long particles. This sorting may have occurred because ruminants can make dietary choices based on nutritional demands and postingestive feedback (Provenza, 1995; Forbes and Kyriazakis, 1995). Postweaned calves may prefer starter to hay to compensate for decreased energy intake from MR, which may explain why MIX calves tried to sort against long particles.

Perhaps due to the higher NDFIP by MIX calves, DMI and consequently ADG were also lower. This outcome is consistent with meta-analysis results showing that ADG is lower when calves are provided starter and a forage source as a mixture rather than separate 


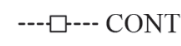

A

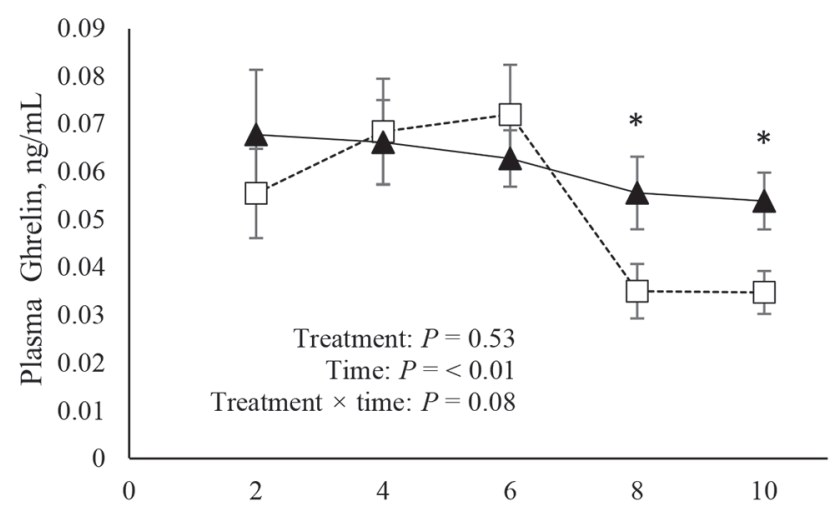

B

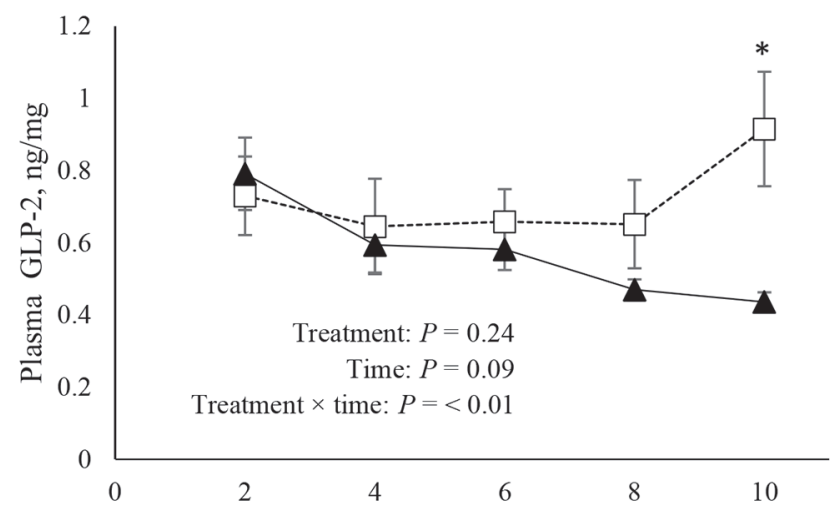

C

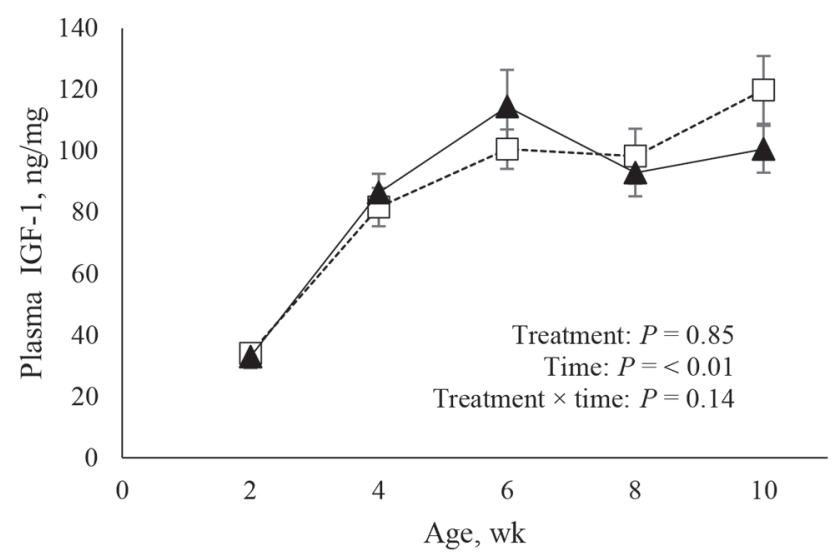

D

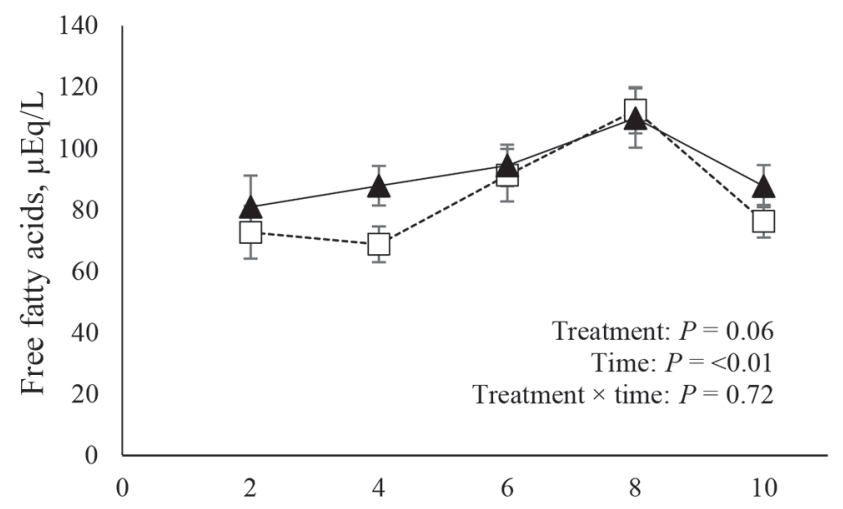

E

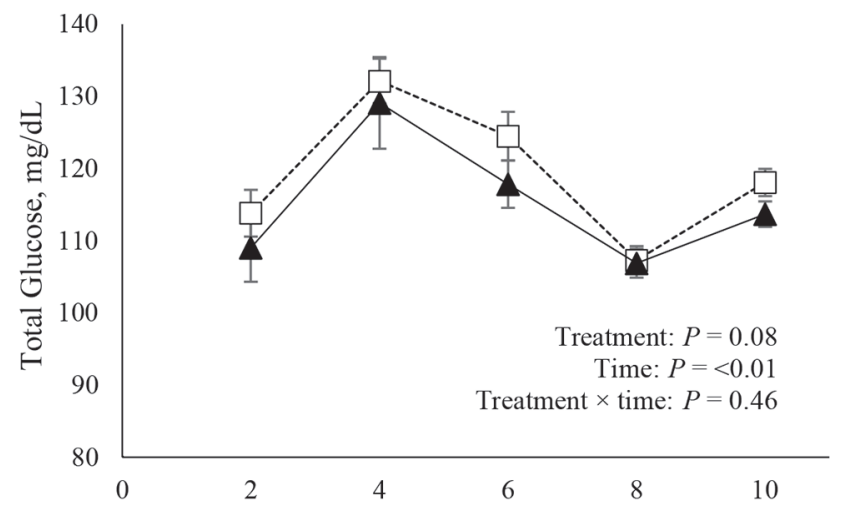

F

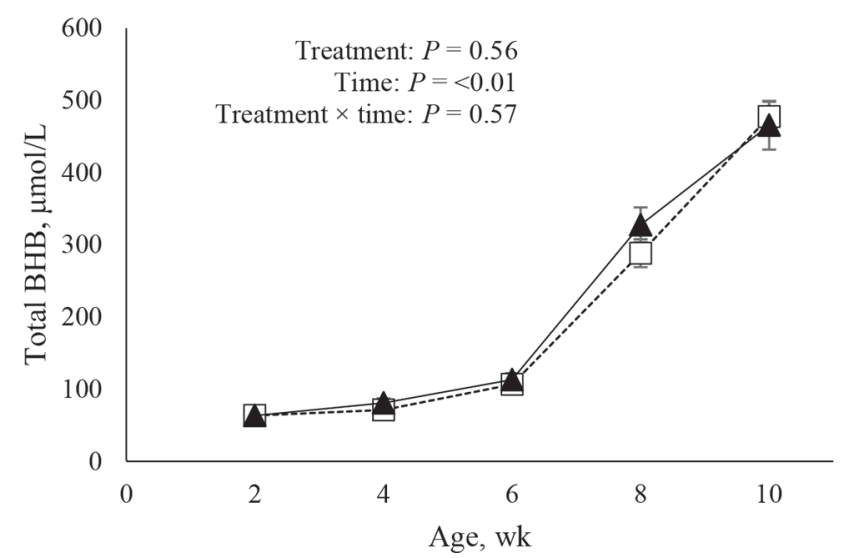

Figure 2. Plasma concentrations of (A) plasma ghrelin, (B) plasma glucagon-like peptide 2 (GLP-2), (C) plasma IGF-1, (D) total free fatty acids, (E) total glucose, and (F) total BHB for calves fed calf starter and hay as separate components (COMT) or as a mixture (MIX). Results are expressed as LSM \pm SEM. ${ }^{*}$ Differences between treatments at each time point are significant $(P<0.05)$. 
components (Imani et al., 2017). Mitchell and Heinrichs (2019) found that increasing hay inclusion rate beyond $10 \%$ decreased intake and growth in calves less than 16 wk old. Similarly, Aragona et al. (2019) reported that DMI of postweaned calves increased from 0 to $5 \%$ hay, but DMI and ADG decreased beyond $5 \%$. The findings of the present and previous studies may suggest that when hay mixed with starter is provided, $10 \%$ hay is too high for calves in the first month of the postweaning period because it may reduce intake and growth. However, other studies have shown that calves' hay intake can range between 5 to $30 \%$ of total DMI when they are offered both hay and starter (Khan et al., 2011b; Castells et al., 2012; Miller-Cushon et al., 2013). This variation may be explained by the characteristics of forage used in each study (Miller-Cushon and DeVries, 2015) because intake can be affected by forage source (Castells et al., 2012) and chop length (Montoro et al., 2013; Nemati et al., 2015). Given that different hay proportions, sources, and chop lengths may result in different intakes of solid feed, hay characteristics should be considered when providing solid feed to calves.

In addition to rumen fill, voluntary intake can be controlled by starch intake because rapid starch fermentation decreases rumen $\mathrm{pH}$ and leads to depressed DMI (Khan et al., 2007). However, in the present study rumen fill seemed to play a greater role than rumen fermentation in feed intake regulation because NDF intake $(\mathrm{g} / \mathrm{d})$ was similar between treatments, while starch intake was lower for MIX calves. If voluntary intake was controlled by starch intake, starch intake between treatments would have been similar because starchinduced rumen fermentation would limit feed intake of calves (Khan et al., 2007; Nemati et al., 2015). Starch may have had a greater impact on solid feed intake if starch content of starter was greater than that used in the present study as additional fermentation would have occurred, perhaps reducing intake (Suárez et al., 2006). The physical form of calf starter may also play a role in animal response as calves fed texturized calf starter have greater starter intake than calves fed pelleted starter (Franklin et al., 2003; Bach et al., 2007).

Hormones. Ghrelin responds to nutrient intake, with larger meals being more effective in lowering plasma ghrelin concentrations (Callahan et al., 2004; Blom et al., 2005; Cummings, 2006), perhaps through the production of VFA, which lower plasma ghrelin concentration (Fukumori et al., 2011; 2012). Calves with lower intake display higher plasma concentrations of active ghrelin (Bohan et al., 2007), such as MIX calves in wk 8 and 10. The lower starch intake of postweaned MIX calves may have resulted in less rumen fermentation, lower production of VFA, and overall higher plasma ghrelin concentrations (Fukumori et al., 2011, 2012). Starch intake was similar between treatments in the preweaning and weaning periods, which likely explains why no difference in plasma ghrelin concentration was observed during those periods. Additionally, the ghrelin secretory system has been suggested to be immature in calves 3 mo or younger (Miura et al., 2004), thus the calves in the present study may not have produced enough ghrelin for significant differences to be observed before wk 8 .

Intake likely also influenced plasma GLP-2 concentrations in the present study, with lower intake of starch by MIX calves stimulating less GLP-2 production than in CONT calves. A part of starch ferments to butyrate in the rumen (Kotarski et al., 1992), which increases plasma GLP-2 concentration (Górka et al., 2009; Elsabagh et al., 2017). In calves, GLP-2 has been shown to promote proliferation of intestinal crypt cells, increase nutrient absorption and gut integrity, and decrease apoptosis and gut mucosal epithelium inflammation (Taylor-Edwards et al., 2011, 2012; Connor et al., 2013). Each of these GLP-2 functions can contribute to gastrointestinal development, preventing gastrointestinal infections and improving calf feed efficiency and welfare (Steele et al., 2016). The lack of differences in plasma GLP-2 concentrations between treatments before wk 10 was possibly due to lower intake of solid feed, and previous research suggested that a calorie threshold must be met for GLP-2 secretion to increase (Dubé and Brubaker, 2004; Castro et al., 2016). The current study demonstrated that nutritional management can affect GLP-2 secretion in calves in the first month of the postweaning period. Lower plasma GLP-2 concentration in MIX calves may be associated with less gut development, but gut weight was not measured in the current study. Effects of GLP-2 on gut development need to be evaluated in future studies.

\section{CONCLUSIONS}

The results of the present study suggest that mixing hay with starter has little effect on feed intake, growth, and plasma metabolites and hormones of calves during the preweaning period. During weaning, calves fed hay mixed with starter had less NDFIP and lower feed efficiency than calves fed feed as separate components, but growth and plasma metabolite and hormone concentrations were not affected by treatment. During the postweaning period, mixing hay with starter decreased solid feed intake and ADG, as well as plasma concentration of GLP-2, and increased plasma concentration of ghrelin. Calves fed hay mixed with starter had greater NDFIP despite sorting against long particles, resulting 
in greater gut fill, decreased DMI, and a lower ADG compared with calves fed hay and starter separately. We conclude that mixing $10 \%$ hay with calf starter does not promote intake and ADG compared with providing hay and calf starter separately.

\section{ACKNOWLEDGMENTS}

The authors thank Yudai Inabu and Chika Nii of Hiroshima University for their technical assistance in sample analysis. The authors have stated no conflicts of interest.

\section{REFERENCES}

Allen, M. S. 1997. Relationship between fermentation acid production in the rumen and the requirement for physically effective fiber. J. Dairy Sci. 80:1447-1462. https://doi.org/10.3168/jds.S0022 -0302(97)76074-0.

AOAC. 1990. Official Methods of Analysis. 15th ed. Association of Official Analytical Chemists, Arlington, VA.

AOAC International. 2002. Official Methods of Analysis. Vol. 1. 17th ed. AOAC International, Arlington, VA.

Aragona, K., T. Dennis, F. Suarez-Mena, J. Quigley, T. Hill, and R. Schlotterbeck. 2019. Effects of increasing dietary hay inclusion on performance and digestion of Holstein calves from 2 to 4 months of age. Abstract \#M144. American Dairy Science Association Annual Mtg., Cincinnati, OH.

Bach, A., A. Giménez, J. L. Juaristi, and J. Ahedo. 2007. Effects of physical form of a starter for dairy replacement calves on feed intake and performance. J. Dairy Sci. 90:3028-3033. https://doi .org/10.3168/jds.2006-761.

Bach, A., J. J. Villalba, and I. R. Ipharraguerre. 2012. Interactions between mild nutrient imbalance and taste preferences in young ruminants. J. Anim. Sci. 90:1015-1025. https://doi.org/10.2527/ jas.2011-4176.

Beiranvand, H., G. R. Ghorbani, M. Khorvash, and M. Kazemi-Bonchenari. 2014a. Forage and sugar in dairy calves' starter diet and their interaction on performance, weaning age and rumen fermentation. J. Anim. Physiol. Anim. Nutr. (Berl.) 98:439-445. https:// doi.org/10.1111/jpn.12089.

Beiranvand, H., G. R. Ghorbani, M. Khorvash, A. Nabipour, M. Dehghan-Banadaky, A. Homayouni, and S. Kargar. 2014b. Interactions of alfalfa hay and sodium propionate on dairy calf performance and rumen development. J. Dairy Sci. 97:2270-2280. https: //doi.org/10.3168/jds.2012-6332.

Bertoni, G., E. Trevisi, X. Han, and M. Bionaz. 2008. Effects of inflammatory conditions on liver activity in the puerperium and consequences for performance in dairy cows. J. Dairy Sci. 91:33003310. https://doi.org/10.3168/jds.2008-0995.

Blom, W. A., A. Stafleu, C. de Graaf, F. J. Kok, G. Schaafsma, and H. F. Hendriks. 2005. Ghrelin response to carbohydrate-enriched breakfast is related to insulin. Am. J. Clin. Nutr. 81:367-375. https://doi.org/10.1093/ajcn.81.2.367.

Bohan, M., M. Foote, B. Nonnecke, and D. C. Beitz. 2007. Plane of nutrition affects plasma ghrelin concentrations in neonatal calves. ASL R2199. Animal Industry Report 653(1). https://www .iastatedigitalpress.com/air/article/6076/galley/5941/view/.

Callahan, H. S., D. E. Cummings, M. S. Pepe, P. A. Breen, C. C. Matthys, and D. S. Weigle. 2004. Postprandial suppression of plasma ghrelin level is proportional to ingested caloric load but does not predict intermeal interval in humans. J. Clin. Endocrinol. Metab. 89:1319-1324. https://doi.org/10.1210/jc.2003-031267.

Castells, L., A. Bach, G. Araujo, C. Montoro, and M. Terré. 2012. Effect of different forage sources on performance and feeding behav- ior of Holstein calves. J. Dairy Sci. 95:286-293. https://doi.org/10 $.3168 /$ jds.2011-4405.

Castro, J. J., S. Y. Morrison, A. Hosseinni, J. J. Loor, J. K. Drackley, and I. R. Ipharraguerre. 2016. Secretion of glucagon-like peptide-2 responds to nutrient intake but not glucose provision in milk-fed calves. J. Dairy Sci. 99:5793-5807. https://doi.org/10.3168/jds 2015-10519.

Chilibroste, P., S. Tamminga, and H. Boer. 1997. Effects of length of grazing session, rumen fill and starvation time before grazing on dry matter intake, ingestive behavior and dry matter rumen pool sizes of grazing lactating dairy cows. Grass Forage Sci. 52:249-257. https://doi.org/10.1111/j.1365-2494.1997.tb02355.x.

Connor, E. E., S. Kahl, T. H. Elsasser, R. L. Baldwin VI, R. Fayer, M. Santin-Duran, G. L. Sample, and C. M. Evock-Clover. 2013. Glucagon-like peptide 2 therapy reduces negative effects of diarrhea on calf gut. J. Dairy Sci. 96:1793-1802. https://doi.org/10 $.3168 /$ jds.2012-6216.

Costa, J. H. C., N. A. Adderley, D. M. Weary, and M. A. G. von Keyserlingk. 2016. Short communication: Effect of diet changes on sorting behavior of weaned dairy calves. J. Dairy Sci. 99:56355639. https://doi.org/10.3168/jds.2015-10052.

Coverdale, J. A., H. D. Tyler, J. D. Quigley III, and J. A. Brumm. 2004. Effect of various levels of forage and form of diet on rumen development and growth in calves. J. Dairy Sci. 87:2554-2562. https://doi.org/10.3168/jds.S0022-0302(04)73380-9.

Cummings, D. E. 2006. Ghrelin and the short- and long-term regulation of appetite and body weight. Physiol. Behav. 89:71-84. https: //doi.org/10.1016/j.physbeh.2006.05.022.

Dado, R. G., and M. S. Allen. 1995. Intake limitations, feeding behavior, and rumen function of cows challenged with rumen fill from dietary fiber on inert bulk. J. Dairy Sci. 78:118-133. https://doi .org/10.3168/jds.S0022-0302(95)76622-X.

DeVries, T. J., K. A. Beauchemin, and M. A. G. von Keyserlingk 2007. Dietary forage concentrate affects the feed sorting behavior of lactating dairy cows. J. Dairy Sci. 90:5572-5579. https://doi .org/10.3168/jds.2007-0370.

Dubé, P. E., and P. L. Brubaker. 2004. Nutrient, neural and endocrine control of glucagon-like peptide secretion. Horm. Metab. Res. 36:755-760. https://doi.org/10.1055/s-2004-826159.

EbnAli, A., M. Khorvash, G. R. Ghorbani, A. H. Mahdavi, M. Malekkhahi, M. Mirzaei, A. Pezeshki, and M. H. Ghaffari. 2016. Effects of forage offering method on performance, rumen fermentation, nutrient digestibility and nutritional behaviour in Holstein dairy calves. J. Anim. Physiol. Anim. Nutr. (Berl.) 100:820-827. https:/ /doi.org/10.1111/jpn.12442.

Elsabagh, M., Y. Inabu, T. Obitsu, and T. Sugino. 2017. Response of plasma glucagon-like peptide-2 to feeding pattern and intraruminal administration of volatile fatty acids in sheep. Domest. Anim. Endocrinol. 60:31-41. https://doi.org/10.1016/j.domaniend.2017 .03 .001 .

Forbes, J. M., and I. Kyriazakis. 1995. Food preferences in farm animals: Why don't they always choose wisely? Proc. Nutr. Soc. 54:429-440. https://doi.org/10.1079/PNS19950012.

Forbes, J. M., and F. D. Provenza. 2000. Integration of learning and metabolic signals into a theory of dietary choice and food intake. Pages 3-19 in Ruminant Physiology: Digestion, Metabolism, Growth and Reproduction. P. B. Cronjé, ed. CABI Publishing, New York, NY.

Franklin, S. T., D. M. Amaral-Phillips, J. A. Jackson, and A. A. Campbell. 2003. Health and performance of Holstein calves that suckled or were hand-fed colostrum and were fed one of three physical forms of starter. J. Dairy Sci. 86:2145-2153. https://doi .org/10.3168/jds.S0022-0302(03)73804-1.

Fukumori, R., T. Mita, T. Sugino, Y. Hasegawa, M. Kojima, K. Kangawa, T. Obitsu, and K. Taniguchi. 2012. Effects of glucose and volatile fatty acids on blood ghrelin concentrations in calves before and after weaning. J. Anim. Sci. 90:4839-4845. https://doi.org/10 $.2527 /$ jas.2012-5344.

Fukumori, R., T. Sugino, Y. Hasegawa, M. Kojima, K. Kangawa, T. Obitsu, and K. Taniguchi. 2011. Plasma ghrelin concentration is 
decreased by short chain fatty acids in wethers. Domest. Anim. Endocrinol. 41:50-55. https://doi.org/10.1016/j.domaniend.2011 .04 .001 .

Górka, P., Z. M. Kowalski, P. Pietrzak, A. Kotunia, R. Kiljaczyk, J. Flaga, J. J. Holst, P. Guilloteau, and R. Zabielski. 2009. Effect of sodium butyrate supplementation in milk replacer and starter diet on rumen development in calves. J. Physiol. Pharmacol. 60(Suppl. $3): 47-53$.

Gregorini, P., S. A. Gunter, C. A. Masino, and P. Beck. 2007. Effects of ruminal fill on short-term herbage intake rate and grazing dynamics of beef heifers. Grass Forage Sci. 62:346-354. https://doi .org/10.1111/j.1365-2494.2007.00589.x.

Hill, T. M., H. G. Bateman II, J. M. Aldrich, and R. L. Schlotterbeck. 2008. Effects of the amount of chopped hay or cottonseed hulls in a textured calf starter on young calf performance. J. Dairy Sci. 91:2684-2693. https://doi.org/10.3168/jds.2007-0935.

Horadagoda, N. U., K. M. Knox, H. A. Gibbs, S. W. Reid, A. Horadagoda, S. E. Edwards, and P. D. Eckersall. 1999. Acute phase proteins in cattle: Discrimination between acute and chronic inflammation. Vet. Rec. 144:437-441. https://doi.org/10.1136/vr .144.16.437.

Imani, M., M. Mirzaei, B. Baghbanzadeh-Nobari, and M. H. Ghaffari. 2017. Effects of forage provision to dairy calves on growth performance and rumen fermentation: A meta-analysis and metaregression. J. Dairy Sci. 100:1136-1150. https://doi.org/10.3168/ jds.2016-11561.

Kertz, A. F., L. R. Prewitt, and J. P. Everett Jr.. 1979. An early weaning calf program: Summarization and review. J. Dairy Sci. 62:1835-1843. https://doi.org/10.3168/jds.S0022-0302(79)83508 -0 .

Keunen, J. E., J. C. Plaizier, L. Kyriazakis, T. F. Duffield, T. M. Widowski, M. I. Lindinger, and B. W. McBride. 2002. Effects of a subacute ruminal acidosis model on the diet selection of dairy cows. J. Dairy Sci. 85:3304-3313. https://doi.org/10.3168/jds .S0022-0302(02)74419-6.

Khafipour, E., D. O. Krause, and J. C. Plaizier. 2009. A grain-based subacute ruminal acidosis challenge causes translocation of lipopolysaccharide and triggers inflammation. J. Dairy Sci. 92:10601070. https://doi.org/10.3168/jds.2008-1389.

Khan, M. A., H. J. Lee, W. S. Lee, H. S. Kim, S. B. Kim, K. S. Ki, S. J. Park, J. K. Ha, and Y. J. Choi. 2007. Starch source evaluation in calf starter: I. Feed consumption, body weight gain, structural growth, and blood metabolites in Holstein calves. J. Dairy Sci. 90:5259-5268. https://doi.org/10.3168/jds.2007-0338.

Khan, M. A., H. J. Lee, W. S. Lee, H. S. Kim, S. B. Kim, S. B. Park, K. S. Baek, J. K. Ha, and Y. J. Choi. 2008. Starch source evaluation in calf starter: II. Ruminal parameters, rumen development, nutrient digestibilities, and nitrogen utilization in Holstein calves. J. Dairy Sci. 91:1140-1149. https://doi.org/10.3168/jds.2007-0337.

Khan, M. A., D. M. Weary, and M. A. G. von Keyserlingk. 2011a. Invited review: Effects of milk ration on solid feed intake, weaning, and performance in dairy heifers. J. Dairy Sci. 94:1071-1081. https://doi.org/10.3168/jds.2010-3733.

Khan, M. A., D. M. Weary, and M. A. G. von Keyserlingk. 2011b. Hay intake improves performance and rumen development of calves fed higher quantities of milk. J. Dairy Sci. 94:3547-3553. https://doi .org/10.3168/jds.2010-3871.

Kononoff, P. J., A. J. Heinrichs, and D. R. Buckmaster. 2003. Modification of Penn State forage and total mixed ration particle separator and the effects of moisture content on its measurements. J. Dairy Sci. 86:1858-1863. https://doi.org/10.3168/jds.S0022 -0302(03) 73773-4.

Kotarski, S. F., R. D. Waniska, and K. K. Thurn. 1992. Starch hydrolysis by the ruminal microflora. J. Nutr. 122:178-190. https://doi .org/10.1093/jn/122.1.178.

Kyriazakis, I., and J. D. Oldham. 1993. Diet selection in sheep: The ability of growing lambs to select a diet that meets their crude protein (nitrogen $\times$ 6.25) requirements. Br. J. Nutr. 69:617-629. https://doi.org/10.1079/BJN19930064.
Laarman, A. H., and M. Oba. 2011. Short communication: Effect of calf starter on rumen $\mathrm{pH}$ of Holstein dairy calves at weaning. J. Dairy Sci. 94:5661-5664. https://doi.org/10.3168/jds.2011-4273.

Laarman, A. H., A. L. Ruiz-Sanchez, T. Sugino, L. L. Guan, and M. Oba. 2012a. Effects of feeding a calf starter on molecular adaptations in the ruminal epithelium and liver of Holstein dairy calves. J. Dairy Sci. 95:2585-2594. https://doi.org/10.3168/jds.2011-4788. Laarman, A. H., T. Sugino, and M. Oba. 2012b. Effects of starch content of calf starter on growth and rumen $\mathrm{pH}$ in Holstein calves during the weaning transition. J. Dairy Sci. 95:4478-4487. https:/ /doi.org/10.3168/jds.2011-4822.

Leonardi, C., and L. E. Armentano. 2003. Effect of quantity, quality, and length of alfalfa hay on selective consumption by dairy cows. J. Dairy Sci. 86:557-564. https://doi.org/10.3168/jds.S0022 -0302(03)73634-0.

Miller-Cushon, E. K., R. Bergeron, K. E. Leslie, G. J. Mason, and T. J. DeVries. 2013. Effect of early exposure to different feed presentations on feed sorting of dairy calves. J. Dairy Sci. 96:4624-4633. https://doi.org/10.3168/jds.2013-6670.

Miller-Cushon, E. K., and T. J. DeVries. 2011. Effect of early feed type exposure on diet-selection behavior of dairy calves. J. Dairy Sci. 94:342-350. https://doi.org/10.3168/jds.2010-3382.

Miller-Cushon, E. K., and T. J. DeVries. 2015. Invited review: Development and expression of dairy calf feeding behaviour. Can. J. Anim. Sci. 95:341-350. https://doi.org/10.4141/cjas-2014-163.

Miller-Cushon, E. K., and T. J. DeVries. 2017. Feed sorting in dairy cattle: Causes, consequences, and management. J. Dairy Sci. 100:4172-4183. https://doi.org/10.3168/jds.2016-11983.

Mitchell, L. K., and A. J. Heinrichs. 2019. Impact of increasing grass hay inclusion level on weaned dairy calf growth and metabolism. J. Dairy Sci. 103:263. (Abstr.)

Miura, H., N. Tsuchiya, I. Sasaki, M. Kikuchi, M. Kojima, K. Kangawa, Y. Hasegawa, and Y. Ohnami. 2004. Changes in plasma ghrelin and growth hormone concentrations in mature Holstein cows and three-month-old calves. J. Anim. Sci. 82:1329-1333. https:// doi.org/10.2527/2004.8251329x.

Montoro, C., E. K. Miller-Cushon, T. J. DeVries, and A. Bach. 2013. Effect of physical form of forage on performance, feeding behavior, and digestibility of Holstein calves. J. Dairy Sci. 96:1117-1124. https://doi.org/10.3168/jds.2012-5731.

Nemati, M., H. Amanlou, M. Khorvash, B. Moshiri, M. Mirzaei, M. A. Khan, and M. H. Ghaffari. 2015. Rumen fermentation, blood metabolites, and growth performance of calves during transition from liquid to solid feed: Effects of dietary level and particle size of alfalfa hay. J. Dairy Sci. 98:7131-7141. https://doi.org/10.3168/ jds.2014-9144.

Nocek, J. E. 1997. Bovine acidosis: Implications on laminitis. J. Dairy Sci. 80:1005-1028. https://doi.org/10.3168/jds.S0022 -0302(97)76026-0.

NRC. 2001. Nutrient Requirements of Dairy Cattle. 7th rev. ed. Natl. Acad. Sci., Washington, DC.

Overvest, M. A., R. Bergeron, D. B. Haley, and T. J. DeVries. 2016. Effect of feed type and method of presentation on feeding behavior, intake, and growth of dairy calves fed a high level of milk. J. Dairy Sci. 99:317-327. https://doi.org/10.3168/jds.2015-9997.

Pazoki, A., G. R. Ghorbani, S. Kargar, A. Sadeghi-Sefidmazgi, J. K. Drackley, and M. H. Ghaffari. 2017. Growth performance, nutrient digestibility, ruminal fermentation, and rumen development of calves during transition from liquid to solid feed: Effects of physical forms of starter feed and forage provision. Anim. Feed Sci. Technol. 234:173-185. https://doi.org/10.1016/j.anifeedsci .2017.06.004.

Provenza, F. D. 1995. Postingestive feedback as an elementary determinant of food preference and intake in ruminants. J. Range Manage. 48:2-17. https://doi.org/10.2307/4002498.

Steele, M. A., G. B. Penner, F. Chaucheyras-Durand, and L. L. Guan. 2016. Development and physiology of the rumen and the lower gut: Targets for improving gut health. J. Dairy Sci. 99:4955-4966. https://doi.org/10.3168/jds.2015-10351. 
Suárez, B. J., C. G. Van Reenen, G. Beldman, J. van Delen, J. Dijkstra, and W. J. J. Gerrits. 2006. Effects of supplementing concentrates differing in carbohydrate composition in veal calf diets: I. Animal performance and rumen fermentation characteristics. J. Dairy Sci. 89:4365-4375. https://doi.org/10.3168/jds.S0022 -0302(06)72483-3.

Suárez, B. J., C. G. Van Reenen, N. Stockhofe, J. Dijkstra, and W. J. J. Gerrits. 2007. Effect of roughage source and roughage to concentrate ratio on animal performance and rumen development in veal calves. J. Dairy Sci. 90:2390-2403. https://doi.org/10.3168/ jds.2006-524.

Sugino, T., Y. Hasegawa, Y. Kikkawa, J. Yamaura, M. Yamagishi, Y. Kurose, M. Kojima, K. Kangawa, and Y. Terashima. 2002. A transient ghrelin surge occurs just before feeding in a scheduled meal-fed sheep. Biochem. Biophys. Res. Commun. 295:255-260. https://doi.org/10.1016/S0006-291X(02)00654-X.

Taylor-Edwards, C. C., D. G. Burrin, J. J. Holst, K. R. McLeod, and D. L. Harmon. 2011. Glucagon-like peptide-2 (GLP-2) increases small intestinal blood flow and mucosal growth in ruminating calves. J. Dairy Sci. 94:888-898. https://doi.org/10.3168/jds.2010 -3540 .

Taylor-Edwards, C. C., D. G. Burrin, N. B. Kristensen, J. J. Holst, K. R. McLeod, and D. L. Harmon. 2012. Glucagon-like peptide-2 (GLP-2) increases net amino acid utilization by the portal-drained viscera of ruminating calves. Animal 6:1985-1997. https://doi.org/ 10.1017/S175173111200095X

Trevisi, E., A. Zecconi, G. Bertoni, and R. Piccinini. 2010. Blood and milk immune and inflammatory profiles in periparturient dairy cows showing a different liver activity index. J. Dairy Res. 77:310317. https://doi.org/10.1017/S0022029910000178.

\section{ORCIDS}

L. E. Engelking ๑ https://orcid.org/0000-0003-3026-1757

T. Sugino $\odot$ https://orcid.org/0000-0001-5502-3451

M. Oba ๑ https://orcid.org/0000-0001-8057-3500 